\title{
Antena Array Mikrostrip Dual Beam Untuk Aplikasi Sensor Radar Doppler Dual Beam Microstrip Antenna Array for Doppler Radar Sensor Applications
}

\author{
Pamungkas Daud $^{\mathrm{a}}{ }^{*}$ dan Niluh Sri Andayani ${ }^{\mathrm{b}}$ \\ ${ }^{a}$ Pusat Penelitian Elektronika dan Telekomunikasi LIPI, Bandung \\ Pusat Penelitian Elektronika dan Telekomunikasi, Lembaga Ilmu Pengetahuan Indonesia \\ Komplek LIPI Gedung 20 Lantai 4, Jl Sangkuriang, Bandung 40135, Indonesia \\ ${ }^{b}$ Fakultas Elektro dan Komunikasi ITTelkom, Bandung
}

\begin{abstract}
Abstrak
Sekarang ini jumlah kendaraan meningkat dengan pesatnya, sementara sarana jalan masih tertinggal baik pertambahannya maupun kualitas jalan serta pemeliharaan, menyebabkan kemacetan lalu lintas sering terjadi dan jumlah kecelakaan kendaraan meningkat pula. Pengontrolan lalu lintas yang baik sangat dibutuhkan untuk efisiensi dan meningkatkan keselamatan pengguna jalan. Sebuah sensor radar doppler dapat digunakan untuk mendeteksi laju kecepatan relatif kendaraan, yakni antara mobil dan obstacle sehingga dapat digunakan untuk menghindari terjadinya kecelakaan dan dapat memantau kepadatan lalu lintas yang terjadi. Radar dirancang untuk kemudahan navigasi dan bisa digunakan untuk mendeteksi kecepatan suatu benda yang bergerak dengan cara mendeteksi energi dari suatu benda yang bergerak tersebut sekaligus menentukan posisinya. Dalam tulisan ini dibahas mengenai desain dan implementasi antena yang mampu mendukung aplikasi sensor radar doppler. Antena ini dirancang menggunakan antena mikrostrip dual beam yang bekerja pada frekuensi $10 \mathrm{GHz}$. Software yang digunakan untuk perancangan dan simulasi antena ini adalah Ansoft HFSS 10. Penelitian ini dimulai dengan menghitung dimensi antena sesuai rumus yang ada. Dimensi hasil perhitungan akan digunakan pada proses simulasi. Modifikasi dimensi antena digunakan sebagai cara untuk mendapatkan hasil yang optimum dalam simulasi, kemudian dimensi optimum tersebut digunakan dalam proses pabrikasi. Spesifikasi antena yang dibuat memiliki karakteristik bekerja pada frekuensi $10 \mathrm{GHz}$ dengan bandwidth $60 \mathrm{MHz}$ pada VSWR $\leq$ 1,5 , serta memiliki gain sebesar $12,42 \mathrm{dBi}$.
\end{abstract}

Kata kunci: antena mikrostrip, sensor radar doppler, bandwidth, VSWR.

\section{Abstract}

The number of vehicles is increasing rapidly, while the roads are still lagging behind both increase and quality as well as maintenance of roads, causing traffic jams often occur and the number of vehicle accidents increase as well. Traffic control is needed for good efficiency and to improve the safety of road users. A doppler radar sensor can be used to detect the rate of the relative speed of vehicles, i.e. between car and obstacle so it can be used to avoid accidents and can monitor the traffic that occurs. The radar is designed for ease navigation and can be used to detect the speed of a moving object by detecting the energy of a moving object and to determine their position at any given time. Design and implementation of antenna which is capable in supporting applications of doppler radar sensors, is discussed in this issue. This antenna is designed using a dual beam microstrip antenna that works on a frequency of $10 \mathrm{GHz}$. Software used for design and simulation of this antenna is the Ansoft HFSS10. This study is begun by calculating the dimensions of the antenna according to the existing formula. The dimensions of the calculation results will be used in the simulation process. Modification of antenna dimensions are used as a way to get optimum results in the simulation, then the optimum dimensions used in the manufacturing process. Specification of the antenna built to work on a frequency of $10 \mathrm{GHz}$ with a bandwidth of $60 \mathrm{MHz}$ at VSWR $\leq 1.5$, and has a gain of $12.42 \mathrm{dBi}$.

Keywords: microstrip antenna, doppler radar sensors, bandwidth, VSWR.

\section{Pendahuluan}

Jumlah kendaraan yang semakin meningkat dengan pesatnya, sementara sarana jalan masih tertinggal baik pertambahannya maupun kualitas serta pemeliharaan, menyebabkan kemacetan lalu lintas sering terjadi dan jumlah kecelakaan kendaraan ikut meningkat.

\footnotetext{
* Corresponding Author.
}

Email: pmkdaud@gmail.com

Received: May 24, 2013; Revised: June 16, 2013

Accepted: June 18, 2013

Published: June 30, 2013

(C) 2013 PPET - LIPI

doi : 10.14203/jet.v13.6-13
Pengontrolan lalu lintas yang baik sangat dibutuhkan untuk meningkatkan efisiensi dan keselamatan pengguna jalan. Keadaan ini memacu industri otomotif untuk mengembangkan sejumlah sistem aktif maupun pasif untuk meningkatkan keselamatan berkendaraan di jalan raya. Sebuah sensor radar doppler dapat mengukur kecepatan relatif antara mobil dan obstacle sehingga dapat digunakan untuk menghindari kecelakaan dan hanya memantau kepadatan lalu lintas yang tinggi. Penelitian ini mengembangkan antena array mikrostrip dual beam untuk aplikasi sensor radar doppler yang mampu menghasilkan gain $10 \mathrm{dBi}$, bandwidth yang sesuai dengan spesifikasi radar yaitu 
sebesar $60 \mathrm{MHz}$ dan pola radiasi bidirectional pada sudut $30^{\circ}$ dan $-30^{\circ}$.

\section{LANDASAN TEORI}

\section{A. Antena Mikrostrip}

Antena mikrostrip merupakan salah satu jenis antena yang berbentuk papan tipis dan mampu bekerja pada frekuensi yang sangat tinggi. Antena microstrip dibuat tiga lapisan bahan, yaitu lapisan patch, substrat dielektrik, dan groudplane. Pada lapisan patch dan groundplane terbuat dari bahan konduktor.

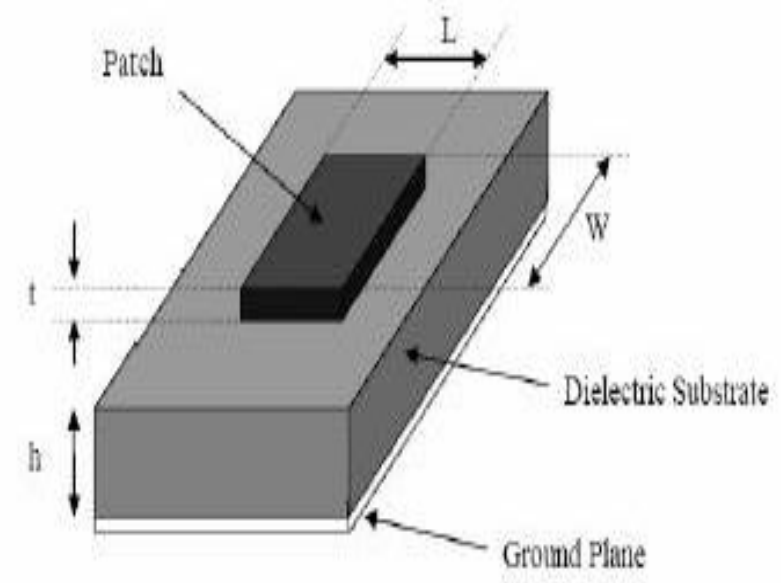

Gambar 1. Struktur Antena Mikrostrip.

Menurut teori saluran transmisi, antena mikrostrip empat persegi panjang dapat dimodelkan sebagai dua buah slot peradiasi paralel yang terpisahkan jarak sebesar setengah panjang gelombang dalam bahan Ketika gelombang datang dari saluran pencatu menemui perubahan kasar (discontinue) pada sisi input konduktor antena mikrostrip, medan listriknya akan menyebar ke udara bebas juga pada sisi berikutnya setelah melewati patch atau konduktor yang dianggap sebagai saluran transmisi. Nilai $\mathrm{W} \ll \lambda$, jika nilai $\mathrm{W}$ diperbesar maka radiasi dari tepi patch dapat dikurangi. Untuk rektangular patch nilai $\mathrm{W}=L$ dan nilainya haruslah $<\lambda / 2$, di mana $\lambda$ adalah panjang gelombang medium dielektrik dengan $\lambda$ adalah panjang gelombang di ruang hampa.

$$
=\frac{\mathrm{c}}{\mathrm{f}}
$$

$\lambda_{g}$ adalah panjang gelombang medium dielektrik

$$
\mathrm{g}=\frac{\mathrm{c}}{\mathrm{fr} \sqrt{\varepsilon_{e f f}}}
$$

Berdasarkan formula Jackson dan Alexopolus maka formula $\mathrm{W}$ dan $\mathrm{L}$ adalah [1]

$$
\mathrm{W}=\frac{0.49 \lambda_{\mathrm{o}}}{\sqrt{\varepsilon_{r}}}
$$

$\varepsilon_{\text {eff }}$ adalah konstanta dielektrik efektif patch yang dapat diperoleh dari

$$
\varepsilon_{e f f}=\frac{\varepsilon_{r}+1}{2}+\frac{\varepsilon_{r}-1}{2}\left[1+\frac{12 h}{W}\right]^{-\frac{1}{2}}
$$

\section{B. Corner Feed Patch Antenna}

Corner feed patch antenna adalah antena rektangular yang dicatu di salah satu ujungnya. Pencatuan seperti ini akan menghasilkan adanya lebar feed junction $\left(\mathrm{W}_{\mathrm{j}}\right)$. Perubahan lebar dari feed junction ini akan menyebabkan perubahan frekuensi resonansi [1].

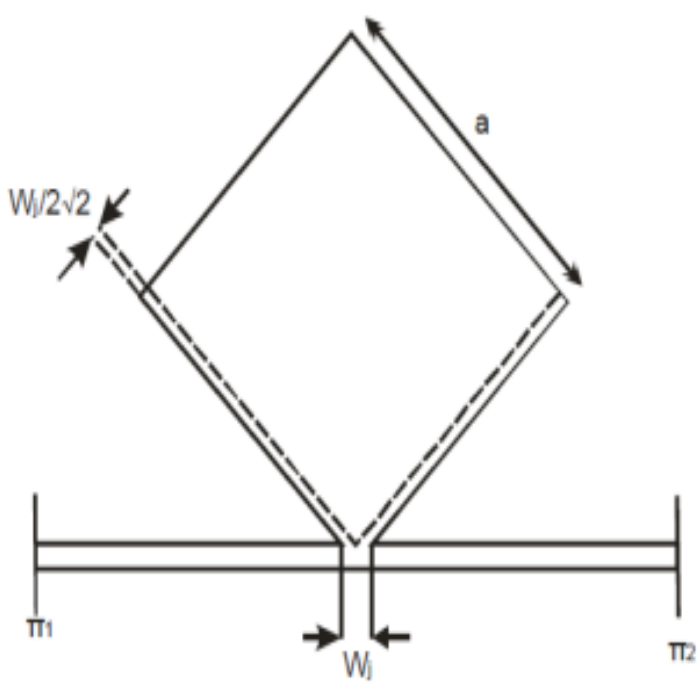

Gambar 2.Corner Feed Patch Antenna.

Nilai dari frekuensi resonansi didapatkan dari rumus berikut

$$
\mathrm{fr}=\frac{\mathrm{c}}{2 \sqrt{\varepsilon_{\text {eff }}\left(\mathrm{a}-\frac{\mathrm{Wj}}{2 \sqrt{2}}+2 \Delta \mathrm{W}\right)}}
$$

$\mathrm{W}_{j}$ merupakan lebar dari sambungan pencatuan antena, di mana lebar sambungan pencatuan antena akan seiring dengan bertambahnya frekuensi resonansi. Pencatuan di ujung antena akan memberikan impedansi input yang tinggi dan sesuai untuk antena susunan seri. Pemodelan ini menunjukkan suatu pemodelan medan dalam yang merupakan penjumlahan dari dua mode amplitudo yang sama yaitu mode $(1,0)$ dan $(0,1)$.

\section{Antena Susunan (Array)}

Antena array terdiri dari konfigurasi elemen yang identik yang disusun sejajar. Ada tiga macam metoda array yaitu linear array, circular array dan planar array. Ketiga metoda ini dipergunakan tergantung dari posisi elemen antena. Antena susunan dibuat untuk meningkatkan gain, mendapatkan diagram arah dengan pola tertentu (beam forming) dan mendapatkan diagram arah dengan pengendalian tertentu (beam streering).

Berdasarkan arus catuannya, antena array digolongkan menjadi uniform dan non uniform. Susunan antena akan disebut uniform jika setiap elemen susunan dicatu dengan amplitudo arus dan fasa catuan $(\beta)$ yang sama besar. Sebaliknya susunan antena dikatakan non uniform jika amplitudo arus catuannya berbeda dengan fasa catuan [2], [3]. Rumus array factor untuk $\mathrm{N}$ buah susunan adalah:

$$
\begin{aligned}
& \mathrm{AF}=\sum_{\mathrm{n}=1}^{\mathrm{N}} \operatorname{ane}^{\mathrm{j}(\mathrm{n}-1) \varphi} \\
& \varphi=\mathrm{kd} \cos \Phi+\beta=\frac{2 \pi \mathrm{d}}{\mathrm{x}} \cos \Phi+\beta
\end{aligned}
$$


di mana:

$k$ : konstanta pergeseran fasa sebesar $2 \pi / \lambda$

$d$ : jarak antar elemen

$\theta$ : sudut main beam antena array

$\beta$ : beda fasa catuan tiap elemen

$a_{n}$ : amplitudo elemen tunggal

\section{Penyepadan Transformator $\lambda / 4$}

Ada beberapa jenis teknik penyepadan dengan menggunakan transformator $\lambda / 4$ yaitu transformator $\lambda / 4$, transformator $\lambda / 4$ bertingkat binomial, stub tapper dan lainnya. Teknik penyepadan yang digunakan pada tulisan ini adalah teknik penyepadan dengan menggunakan transformator $\lambda / 4$ yang dicetak pada bahan yang sama dengan line yang terhubung langsung [4].

$\mathrm{Zl}$

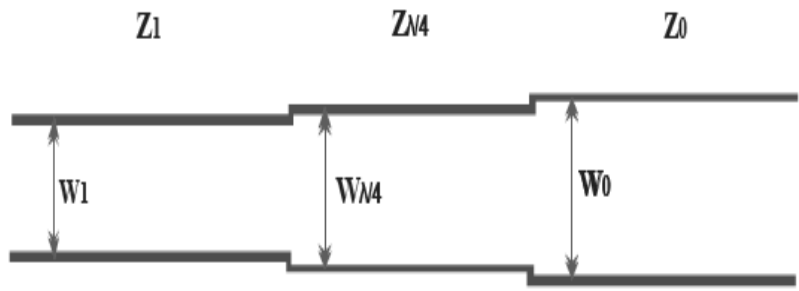

Gambar 3. Transformator $\lambda / 4$

Syarat matching adalah $\mathbf{Z}_{\text {in }}=\mathbf{Z}_{\mathbf{0}}$, sehingga beban dipasang sejauh $\mathrm{d}$ dari trafo $\lambda / 4$. Untuk memperoleh nilai $\mathrm{Z}_{\mathrm{T}}$, dapat digunakan rumus:

$$
\mathrm{Z}_{\mathrm{T}}=\sqrt{Z_{0} Z_{L}}
$$

\section{E. Sensor Radar Doppler}

Radar doppler merupakan jenis radar yang mengukur kecepatan radial dari sebuah objek yang masuk ke dalam daerah tangkapan radar dengan menggunakan efek doppler. Hal ini dilakukan dengan memancarkan sinyal microwave (gelombang mikro) ke objek lalu menangkap refleksinya, dan kemudian dianalisis perubahannya. Radar doppler merupakan jenis radar yang sangat akurat dalam mengukur kecepatan radial. Contoh radar doppler adalah weather radar yang digunakan untuk mendeteksi cuaca.

\section{Perancangan, Simulasi dan Realisas}

\section{A. Spesifikasi Teknik Antena}

Pada perancangan antena terlebih dahulu ditentukan spesifikasi teknik yang sesuai dengan aplikasi yang diinginkan sebagai berikut:

$\begin{array}{ll}\text { - Frekuensi kerja } & : 10 \mathrm{GHz} \\ \text { - Bandwidth } & : 60 \mathrm{MHz} \\ \text { - Impedansi terminal } & : 50 \Omega \\ \text { - VSWR } & : \leq 1,5 \\ \text { - Pola radiasi } & : \text { Bidirectional } \\ \text { - Polarisasi } & : \text { Linier } \\ \text { - Gain } & : \geq 10 \mathrm{dBi}\end{array}$

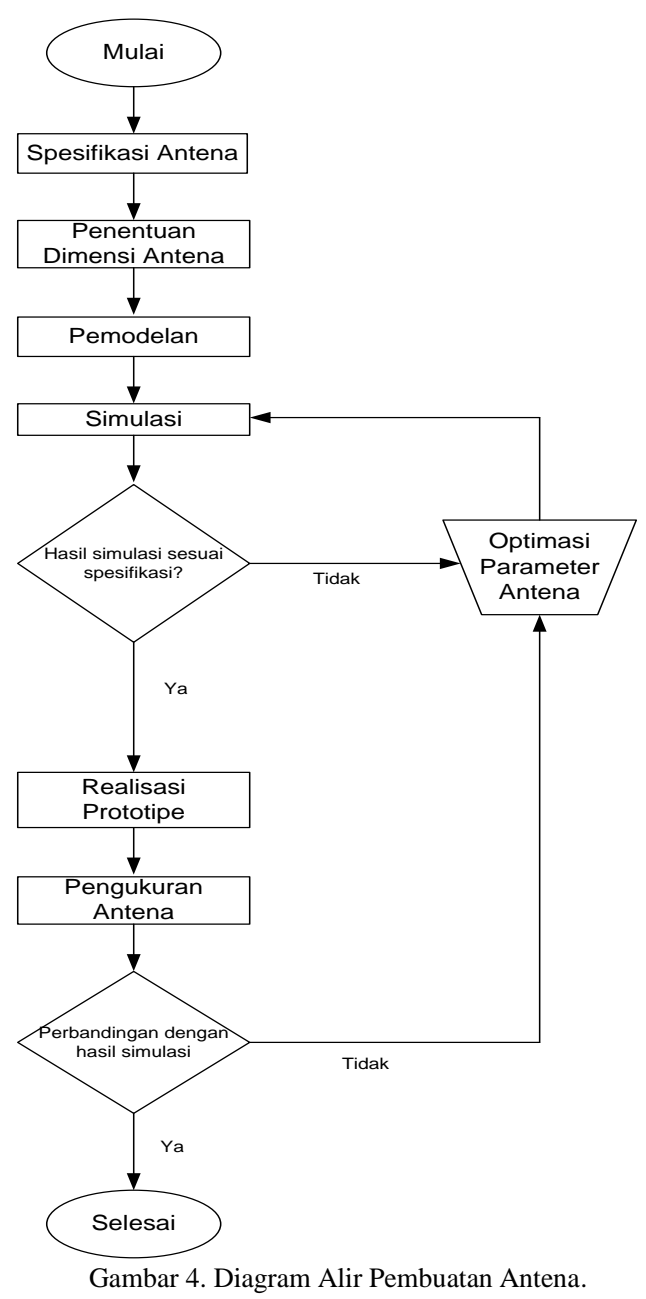

\section{B. Pemilihan Bahan Substrat, Groundplane dan Patch}

Bahan yang digunakan dalam perancangan antena dual beam ini adalah tembaga (copper) pada bagian groundplane, patch dan microstrip line dan RT/Duroid 5880 pada bagian substrat. Pemilihan bahan RT/Duroid 5880 dikarenakan bahan ini bisa bekerja dengan baik pada frekuensi tinggi. Karakteristik dari bahan yang digunakan pada perancangan antena dual beam adalah sebagai berikut:

1. Tembaga
a. Permitivitas relatif $(\varepsilon r) \quad: 1$
b. Permeabilitas relatif $(\mu r) \quad: 0,999991$
c. Ketebalan :0,035 mm

2. RT/Duroid 5880
a. Permitivitas relatif $(\varepsilon r) \quad: 2,2$
b. Permeabilitas relatif $(\mu r) \quad: 1$
c. Ketebalan :0,93 mm
d. Rugi tangensial, $(\tan \delta) \quad: 0,0012$
e. Konduktivitas konduktor : $5,810^{7} \mathrm{~S} / \mathrm{m}$

\section{Perancangan Dimensi Antena}

1) Spesifikasi Satu Patch Rektangular

a) Langkah 1: lebar patch

Secara umum, rectangular patch, lebar dan panjang elemen sama $(W=L)$ dapat dihitung dengan formula [1].

$$
\begin{aligned}
& W=L=\frac{0.49 \lambda_{\mathrm{o}}}{\sqrt{\mathrm{\varepsilon r}}} \\
& W=L=9,91 \mathrm{~mm}
\end{aligned}
$$


b) Langkah 2: konstanta dielektrik effektif

Persamaan untuk konstanta dielektrik effektif di mana $\mathrm{W} / \mathrm{h}>1$ adalah

$$
\begin{aligned}
& \varepsilon_{\text {eff }}=\frac{\varepsilon_{r}+1}{2}+\frac{\varepsilon_{r}-1}{2}\left[1+\frac{12 h}{W}\right]^{-\frac{1}{2}} \\
& \varepsilon_{\text {eff }}=2,0115
\end{aligned}
$$

c) Langkah 3: panjang gelombang

Panjang gelombang di udara dapat dihitung dengan persamaan:

$$
\begin{aligned}
& \lambda=\frac{\mathrm{c}}{\mathrm{f}} \\
& \lambda=30 \mathrm{~mm}
\end{aligned}
$$

dan panjang gelombang di dalam bahan/dielektrik :

$$
\begin{aligned}
& \lambda_{\mathrm{g}}=\frac{\mathrm{c}}{\mathrm{f} \sqrt{\mathrm{\varepsilon r}}} \\
& \lambda_{\mathrm{g}}=20,23 \mathrm{~mm}
\end{aligned}
$$

\section{2) Spesifikasi Susunan}

Antena direksional sederhana yang terdiri dari susunan secara linier dengan elemen antena yang memiliki radiasi kecil, setiap elemennya dicatu dengan sinyal yang identik dari sebuah transmitter. Apabila lebar dari elemen antena array ditambah, maka sidelobe bisa ditekan. Spasi antar elemen $d y$ pada orientasi sumbu $y$ ditujukan untuk men-setting radiasi sirkular dari tiap elemen yang dipancarkan agar sefasa.

Spasi antar dua elemen terdekat adalah sebagai berikut [1]:

$$
\begin{aligned}
& \theta \mathrm{o}=\arcsin \frac{\lambda_{\mathrm{g}}}{2 \mathrm{~d}_{\mathrm{s}}} \\
& \theta \mathrm{o}=30^{\circ} \text { maka } \mathrm{d}_{\mathrm{s}}=\lambda_{\mathrm{g}}
\end{aligned}
$$

Jadi jarak antar elemen terdekat adalah 20,23 mm.

\section{3) Dimensi Substrat dan Groundplane}

Dimensi minimum groundplane yang dibutuhkan diberikan melalui persamaan berikut [4]:

$$
\mathrm{Gp}_{\min }=6 \mathrm{~h}+2 \mathrm{~W}
$$

Dengan demikian untuk tebal substrat yang digunakan yaitu $h=0,93 \mathrm{~mm}$ dan $\mathrm{W}=8,89 \mathrm{~mm}$ maka lebar groundplane dari tiap sisi elemen peradiasi adalah $G p_{\text {min }}=23,36 \mathrm{~mm}$, diperoleh dimensi minimum groundplane untuk satu patch sebesar 23,36x23,36 $\mathrm{mm}^{2}$. Sedangkan untuk penelitian ini menggunakan antena susunan dengan jumlah 4 x 2 elemen maka dimensi groundplane yang digunakan adalah 110x70 $\mathrm{mm}^{2}$ dengan tinggi groundplane sebesar $0,035 \mathrm{~mm}$.

Sedangkan ukuran dimensi substrat sama dengan ukuran dimensi groundplane, yaitu sebesar 110x70 mm dengan tinggi sebesar $0,93 \mathrm{~mm}$. Pemilihan bahan substrat didasari atas keperluan karakteristik antena.

\section{4) Rancangan Hasil Perhitungan}

Berikut ini adalah tabel mengenai ukuran dimensi berdasarkan perhitungan.
TABEL I

Dimensi ANTENA Hasil PeRhitungan

\begin{tabular}{|c|c|}
\hline Komponen & Dimensi \\
\hline Lebar Pacth & $9,91 \mathrm{~mm}$ \\
Panjang Gelombang $\left(\lambda_{\mathrm{d}}\right)$ & $20,23 \mathrm{~mm}$ \\
L1 & $80,92 \mathrm{~mm}$ \\
L2 & $5 \mathrm{~mm}$ \\
W1 & $1,1 \mathrm{~mm}$ \\
W3 & $1,8 \mathrm{~mm}$ \\
Panjang Groundplane & $110 \mathrm{~mm}$ \\
Lebar Groundplane & $70 \mathrm{~mm}$ \\
Tebal Groundplane dan Patch & $0,035 \mathrm{~mm}$ \\
Tebal Substrat & $0,93 \mathrm{~mm}$ \\
\hline
\end{tabular}

\section{5) Jarak Patch dengan Saluran Mikrostrip}

Untuk jarak antara patch dengan saluran mikrostrip dilakukan dengan proses trial and error sehingga didapatkan hasil simulasi terbaik, yaitu memiliki gain yang besar dan sidelobe yang kecil. Optimasi ini dilakukan untuk mendapatkan pola radiasi dual beam sesuai dengan spesifikasi. Optimasi jarak antara patch dengan saluran mikrostrip dilakukan dengan cara membandingkan 3 jarak yang berbeda yaitu: tanpa saluran (0), $\lambda_{\mathrm{g}} / 8$, dan $\lambda_{\mathrm{g}} / 4$.

TABEL II

PERBANDINGAN POLA RADIASI HASIL OPTIMASI

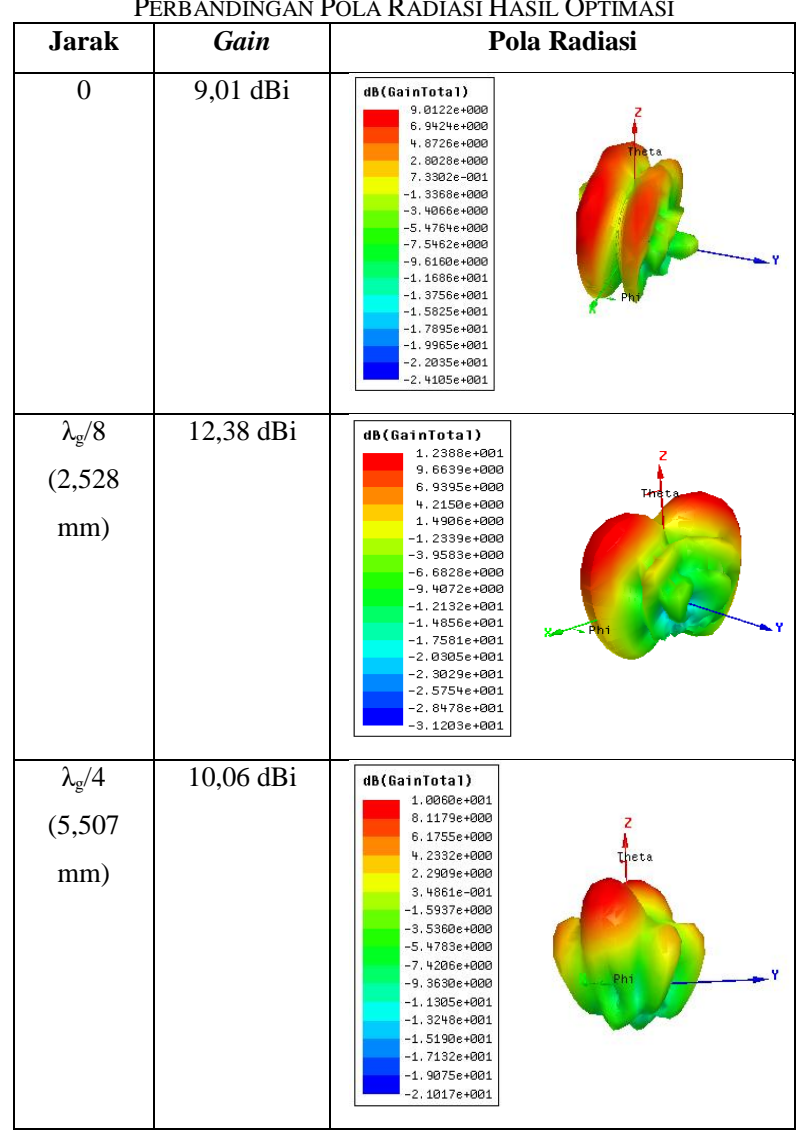

Dari hasil pada ketiga hasil di atas terlihat bahwa hasil terbaik adalah dengan menggunakan saluran sepanjang $\lambda_{\mathrm{g}} / 8$, selain gain yang dihasilkan besar, bentuk pola radiasi sudah memenuhi kriteria dual beam 
yang cukup baik. Hasil yang ditunjukan pada bagian $\lambda_{\mathrm{g}}=0$ atau tanpa saluran kurang baik bentuk dual beamnya, karena arahnya tidak sesuai dengan spesifikasi dan pada saluran $\lambda_{\mathrm{g}} / 4$ sidelobe yang dihasilkan cukup besar.

\section{Simulasi}

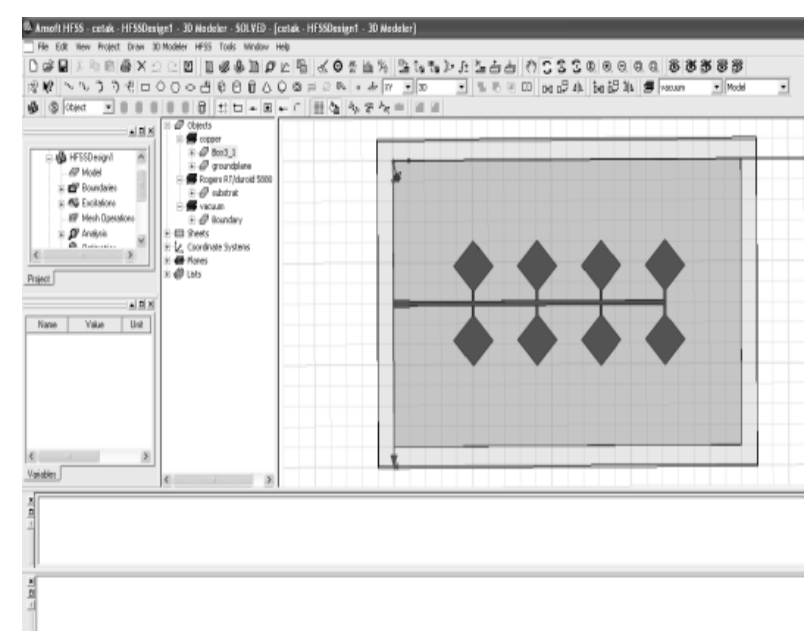

Gambar 5. Rancangan Antena Simulasi.

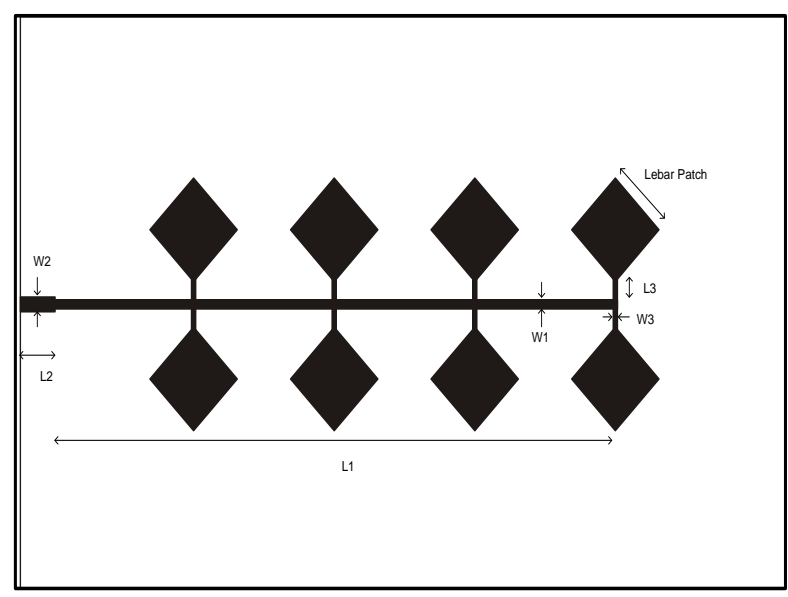

Gambar 6. Konfigurasi Antena Simulasi.

TABEL III

DIMENSI ANTENA HASIL OPTIMASI

\begin{tabular}{|c|c|}
\hline Komponen & Dimensi \\
\hline Lebar Pacth & $8,89 \mathrm{~mm}$ \\
Panjang Gelombang $\left(\lambda_{\mathrm{d}}\right)$ & $20,23 \mathrm{~mm}$ \\
L1 & $80,92 \mathrm{~mm}$ \\
L2 & $5 \mathrm{~mm}$ \\
L3 & $2,528 \mathrm{~mm}$ \\
W1 & $1,1 \mathrm{~mm}$ \\
W2 & $1,8 \mathrm{~mm}$ \\
W3 & $0,6 \mathrm{~mm}$ \\
Panjang Groundplane & $110 \mathrm{~mm}$ \\
Lebar Groundplane & $70 \mathrm{~mm}$ \\
Tebal Groundplane dan Patch & $0,035 \mathrm{~mm}$ \\
Tebal Substrat & $0,93 \mathrm{~mm}$ \\
\hline
\end{tabular}

\section{E. Hasil Simulasi}

1) VSWR, Bandwidth dan Impedansi

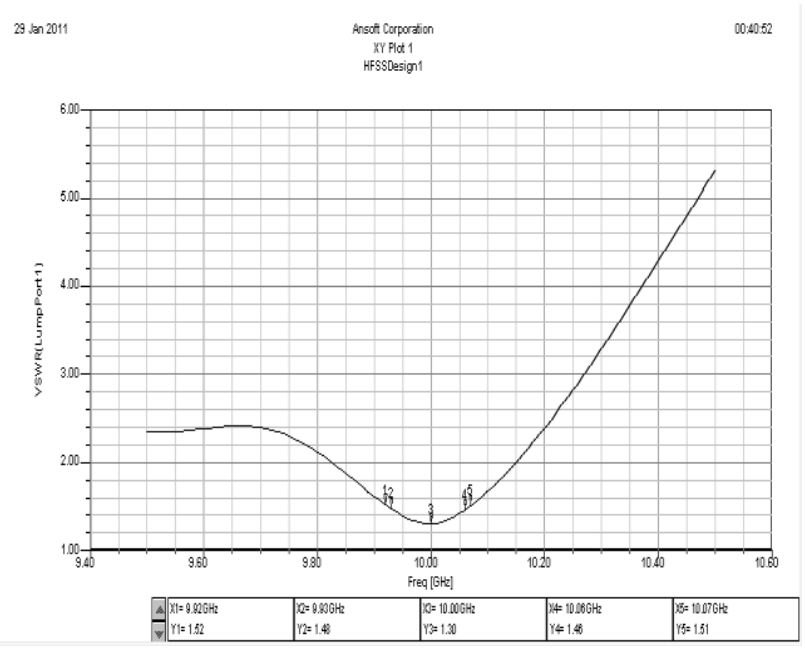

Gambar 7. VSWR Hasil Simulasi.
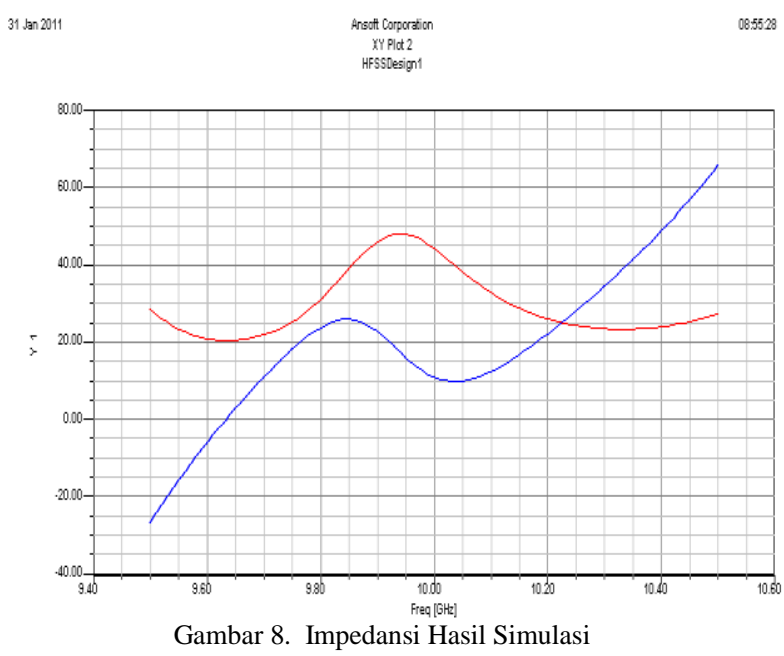

Hasil simulasi menunjukkan bahwa bandwidth 60 $\mathrm{MHz}$ pada frekuensi $9,97 \mathrm{GHz}-10,03 \mathrm{GHz}$ dicapai pada VSWR $<1,35$ dan impedansi sebesar 44,47+j11,28 $\Omega$ atau $45,88 \angle 14,23 \Omega$.

\section{2) Gain dan Pola Radiasi}

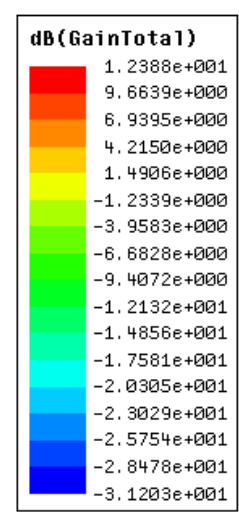

Gambar 9. Gain Hasil Simulasi. 


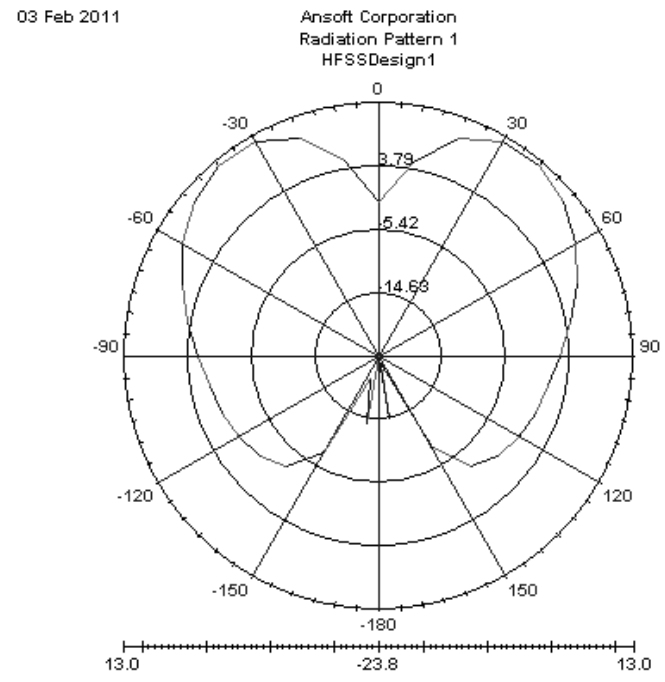

(a)

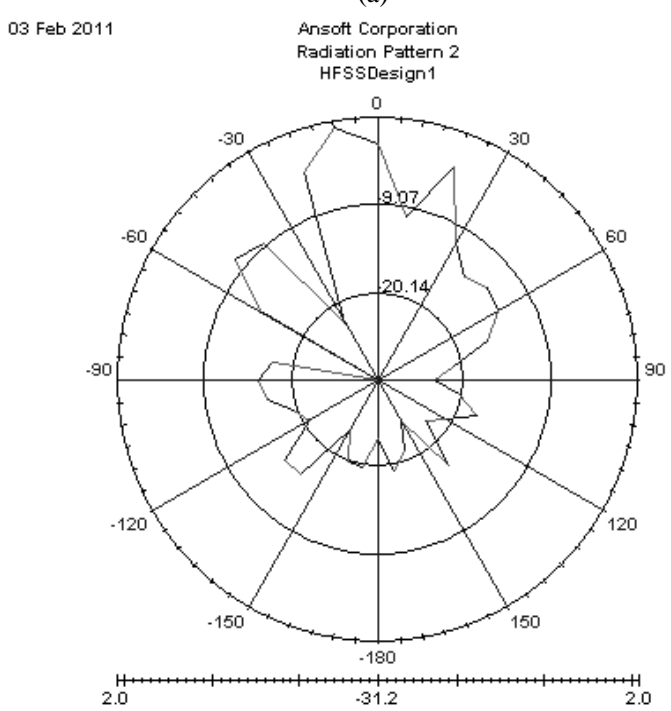

(b)

Gambar 10. Pola Radiasi Hasil Simulasi, (a) Bidang XZ dan (b) Bidang YZ.

Gain hasil simulasi didapatkan sebesar 12,42 dBi dan pola radiasi sudah terlihat sudah berbentuk dual beam. Kedua beam bernilai maksimum saat sudut $30^{\circ}$ (bidirectional). Pola radiasi bidang YZ terlihat bahwa sidelobe cukup besar dan backlobe kecil.

\section{PENGUKuRAN dAN ANALISIS}

\section{A. Alat Ukur}

Alat ukur yang digunakan untuk mengukur antenna pada penelitian ini adalah alat yang mampu digunakan untuk mengukur spesifikasi antena.

1. Network Analyzer, merk: Advantest tipe R3770 (300 KHz - $20 \mathrm{GHz})$, Network Analyzer digunakan dalam pengukuran VSWR, bandwidth, dan impedansi antena.

2. Spectrum Analyzer, merk: $H P$ tipe $8563 \mathrm{E}(30 \mathrm{~Hz}-$ 26,5 GHz) dan Sweep Oscilator, merk: HP 8350 B, alat ukur ini digunakan dalam pengukuran gain, pola radiasi, dan polarisasi dari prototype antena yang akan diukur.
3. Profile Projektor (Nikon V-12B)

Alat ukur ini digunakan untuk pengukuran dimensi fisik antena. Prinsip kerjanya menggunakan efek cahaya untuk mendapatkan bayangan obyek yang diukur.

\section{B. Pengukuran Antena}

\section{1) Pengukuran VSWR, Bandwidth dan Impedansi}

Pengukuran VSWR menggunakan Network Analyzer yaitu dengan membaca parameter $S_{11}$ yang merepresentasikan perbandingan daya yang dikirim ke beban dengan daya yang dipantulkan kembali.

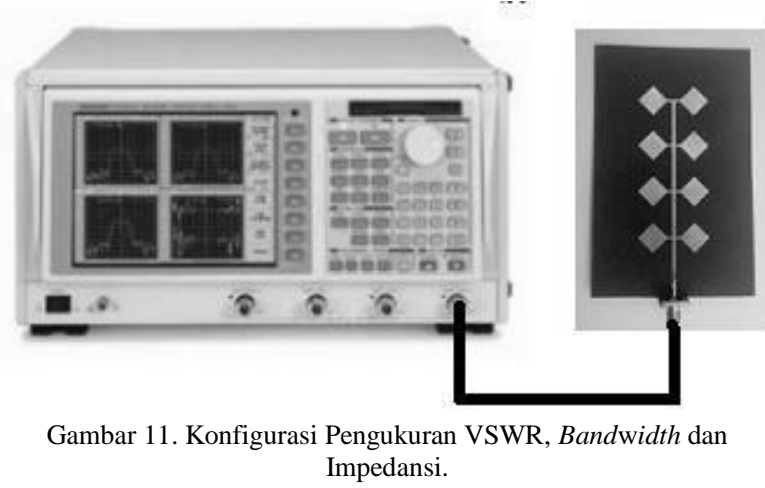

a) Hasil pengukuran VSWR dan bandwidth

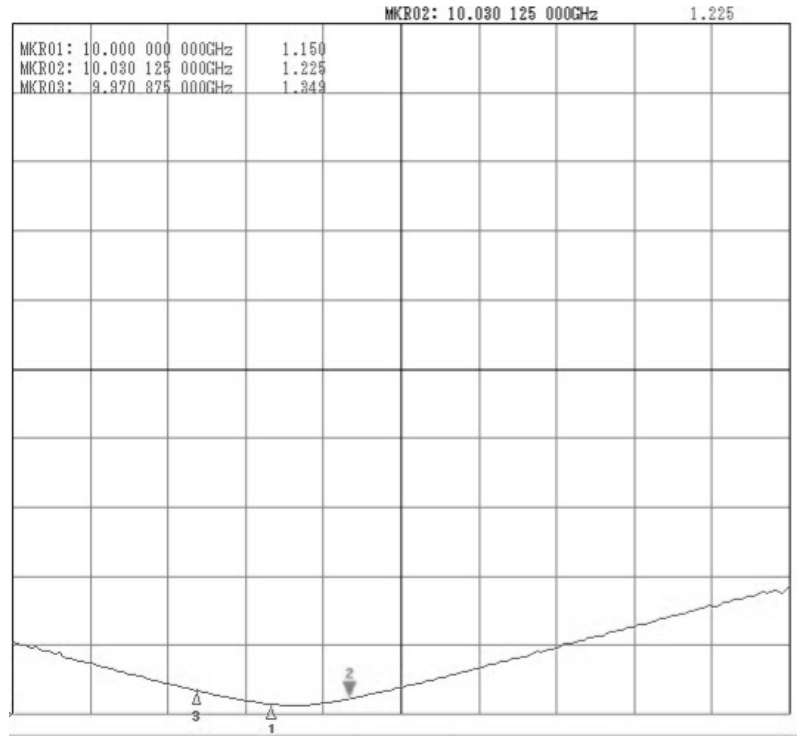

Gambar 12. Hasil Pengukuran VSWR dan Bandwidth.

Bandwidth $60 \mathrm{MHz}$ berada pada frekuensi 9,97 $\mathrm{GHz}-10,03 \mathrm{GHz}$ dicapai pada VSWR $\leq 1,343$ dengan demikian spesifikasi awal di mana bandwith $60 \mathrm{MHz}$ dicapai pada VSWR $\leq 1,5$ telah tercapai. Frekuensi tengah yaitu pada frekuensi $10 \mathrm{GHz}$, VSWR yang terukur adalah 1,150 .

\section{b) Hasil pengukuran impedansi}

Hasil pengukuran menunjukkan bahwa impedansi pada frekuensi tengah $10 \mathrm{GHz}$ dengan impedansi 43,841-j3,762 $\Omega$. 


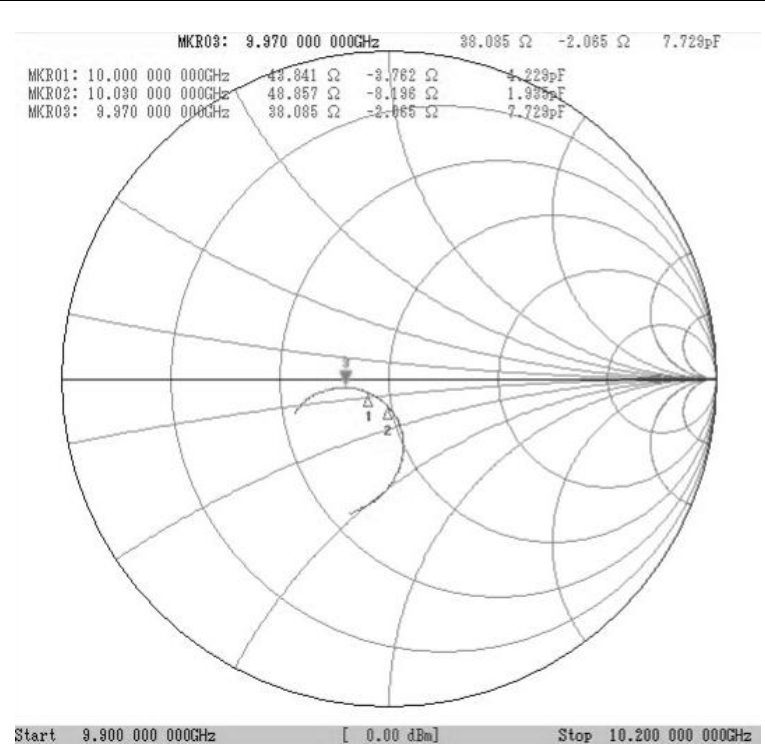

Gambar 13. Hasil Pengukuran Impedansi.

\section{2) Pengukuran Pola Radiasi}

Pola radiasi antena diukur pada daerah medan jauh antena, karena pada daerah tersebut gelombang elektromagnetik yang terpancar tidak bergantung jarak dari antena. Nilai $D$ dari antena array mikrostrip dual beam ini adalah diagonal dari groundplane sebesar 13,04 mm, sedangkan

$$
\lambda=\frac{c}{f}=\frac{3 \times 10^{8}}{10 \times 10^{9}}=0,03 \mathrm{~m} .
$$

Medan jauh dari antena adalah $2 \times R$

$$
\frac{2 D^{2}}{\lambda}=\frac{2(0,13)^{2}}{0,03}=1,12 m
$$

Jadi jarak $\geq 2,24 \mathrm{~m}$.

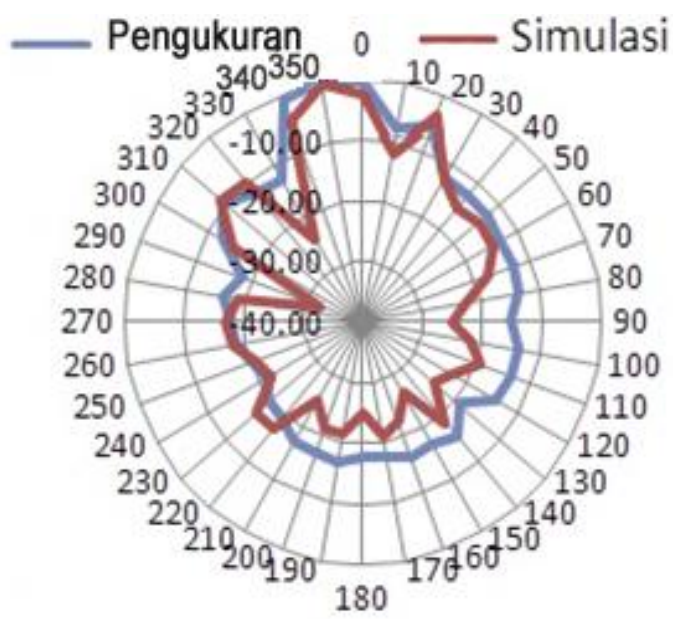

Gambar 14. Pola Radiasi Azimuth YZ antara Hasil Simulasi dan Pengukuran.

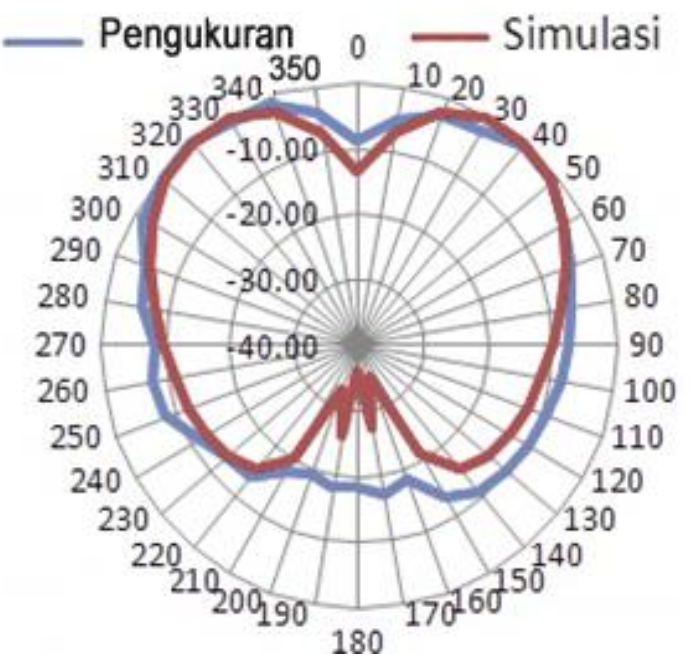

Gambar 15. Pola Radiasi Elevasi XZ antara Hasil Simulasi dan Pengukuran.

\section{3) Pengukuran Pola Polarisasi}

Polarisasi penting karena jika polarisasi antena penerima dan pemancar tidak match maka daya yang diterima akan kecil, atau disebut juga dengan PLF (polarization loss factor). Telah didapatkan data sebagai berikut:

- $\quad$ Daya terima maksimum (sumbu mayor) $=-62,17$ $\mathrm{dBm}=7.94 \times 10^{-8}$ Watt.

- Daya terima minimum (sumbu minor) $=-74,33$ $\mathrm{dBm}=19.18 \times 10^{-10}$ Watt

Dengan analisis rasio kuat medan elektrik, maka dapat diketahui tipe polarisasinya.

Hubungan daya dengan kuat medan elektrik adalah

$$
\begin{aligned}
& P_{\text {watt }}=\frac{E^{2}}{377} x A_{e} \\
& \text { Maka } \\
& E^{2}=\frac{P_{\text {watt }} \times 377}{A_{e}} \rightarrow E=\sqrt{\frac{P_{\text {wat }} \times 377}{A_{e}}}
\end{aligned}
$$

Rasio kuat medan elektrik (numerik) $=$

$$
\begin{aligned}
\frac{\text { Mayor }}{\text { Minor }}= & \frac{\sqrt{P_{\text {wattmayor }} \times 377}}{\sqrt{P_{\text {watt } \min o r} \times 377}} \\
& =\frac{\sqrt{6,06 \times 10^{-10} \times 377}}{\sqrt{3,68 \times 10^{-11} \times 377}} \\
& =\frac{47,8 \times 10^{-5}}{11,8 \times 10^{-5}}=4,05
\end{aligned}
$$

Rasio kuat medan $=10 \log \left(47,8 \times 10^{-5}\right)-10 \log \left(11.8 \times 10^{-5}\right)$

$$
=-33.2+39.28=6.08 \mathrm{~dB}
$$

Dengan mensubstitusikan nilai sumbu mayor dan minor ke persamaan (4.3) dan (4.4) maka didapatkan rasio kuat medan elektrik adalah 4,05 atau 6,08 $\mathrm{dB}$. Karena $1<$ Rasio kuat medan elektrik (numerik) $<\infty$ maka AUT berpolarisasi elips. Hasil ini berbeda dengan polarisasi awal yang diharapkan yaitu polarisasi linear. Perbedaan ini disebabkan oleh ruang pengukuran yang ideal yang mengakibatkan banyaknya sinyal penginterferensi. Selain itu penggeseran antena setiap $10^{\circ}$ tidak presisi dalam perpindahannya, sehingga mengakibatkan adanya perbedaan level daya yang diterima. 


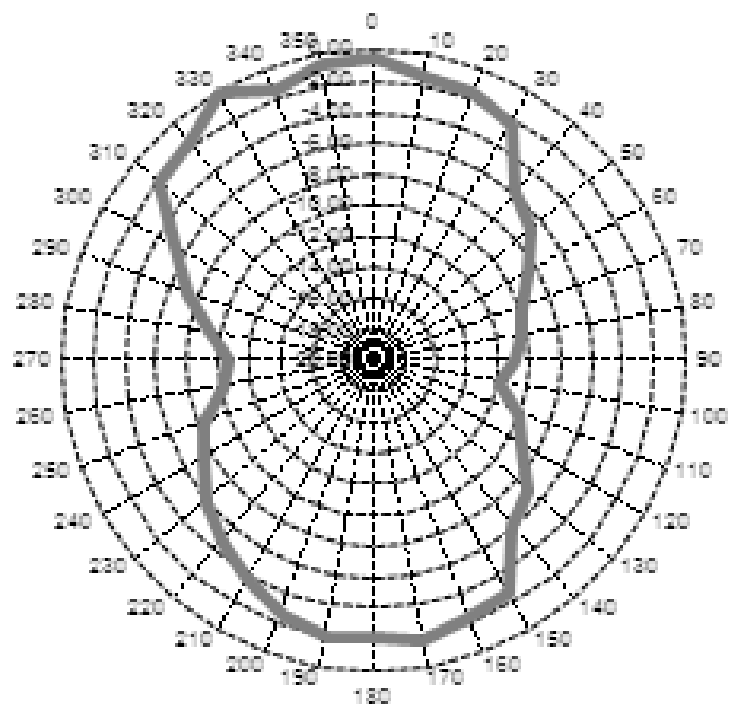

Gambar 16. Pola Polarisasi Hasil Pengukuran

\section{4) Pengukuran Gain}

Pengukuran gain antena menggunakan metode dua antena, di mana kedua antena merupakan antena yang identik. Besarnya gain antena dinyatakan dalam satuan dBi dengan menghitung menggunakan persamaan Friss [5].

$$
\text { Gt. } G r=\frac{W_{r}}{W_{t}}\left(\frac{4 \pi R}{\lambda_{0}}\right)
$$

dimana:

$$
\begin{aligned}
& G t=G r \\
& G t=G r=\frac{1}{2}\left(20 \log \frac{4 \pi R}{\lambda_{0}}+10 \log \frac{W_{r}}{W_{t}}\right)
\end{aligned}
$$

$\mathrm{G}_{\mathrm{t}}=$ gain antena $\mathrm{Tx}$

$\mathrm{Gr}=$ gain antena $\mathrm{Rx}$

$\mathrm{Wr}=$ level daya terima pada $\mathrm{Rx}$

$\mathrm{Wt}=$ level daya terima pada $\mathrm{Tx}$

$\mathrm{R}=$ jarak antara kedua antena saat pengukuran

$\lambda_{0}=$ panjang gelombang yang merambat di udara

Pengukuran gain menggunakan power transmit $\left(\mathrm{W}_{\mathrm{t}}\right)$ sebesar $15 \mathrm{dBm}$. Perbandingan gain antara antena prototype dengan antena simulasi adalah saat simulasi didapatkan gain sebesar 12,28 dBi sedangkan pada pengukuran didapatkan gain sebesar 10,65 dBi. Walaupun terdapat selisih sebesar 1,63 dBi masih bisa ditarik kesimpulan bahwa keduanya sudah memenuhi spesifikasi awal yaitu $\geq 10 \mathrm{dBi}$.

TABEL IV

GAIN HASIL PENGUKURAN

\begin{tabular}{|c|c|c|c|}
\hline $\begin{array}{c}\text { Level Daya } \\
\text { Terima } \\
(-\mathbf{d B m})\end{array}$ & $\begin{array}{c}\text { Level Daya } \\
\text { Terima } \\
(-\mathbf{d B m})\end{array}$ & $\begin{array}{c}\text { Rata-rata } \\
(\mathbf{- d B m})\end{array}$ & $\begin{array}{c}\text { Gain } \\
(\mathbf{d B i})\end{array}$ \\
\hline 52.50 & 53.00 & 52.76 & 9.90 \\
\hline 53.17 & 52.83 & 53.00 & 9.78 \\
\hline 52.83 & 52.67 & 52.75 & 9.91 \\
\hline 53.00 & 53.00 & 53.00 & 9.78 \\
\hline 52.50 & 53.17 & 52.85 & 9.86 \\
\hline 53.17 & 52.83 & 53.00 & 9.78 \\
\hline 52.00 & 52.17 & 52.09 & 10.24 \\
\hline 53.50 & 53.17 & 53.34 & 9.61 \\
\hline 53.17 & 52.83 & 53.00 & 9.78 \\
\hline 52.83 & 53.00 & 52.92 & 9.82 \\
\hline & $\begin{array}{c}\text { Gain } \\
\end{array}$ & & 9,85 \\
\hline
\end{tabular}

\section{5) Pengukuran Fisik}

Pengukuran dilakukan dengan melihat nilai yang tertera pada monitor profile projector. Pengukuran dilakukan dengan menggerakkan dua buah rotor untuk menggerakkan ke arah sumbu $\mathrm{X}$ atau sumbu $\mathrm{Y}$ dan satu buah rotor untuk memperjelas bayangan gambar yang buram.

TABEL V

Perbandingan Dimensi Hasil Simulasi DENGAN HASIL PENGUKURAN

\begin{tabular}{|c|c|c|c|}
\hline Komponen & $\begin{array}{c}\text { Simulasi } \\
(\mathbf{m m})\end{array}$ & $\begin{array}{c}\text { Prototype } \\
(\mathbf{m m})\end{array}$ & $\begin{array}{c}\text { Selisih } \\
(\mathbf{m m})\end{array}$ \\
\hline Lebar Pacth & 8,89 & 9,076 & 0,186 \\
\hline L1 & 80,92 & 79,74 & 1,18 \\
\hline L2 & 5 & 5,149 & 0,149 \\
\hline L3 & 2,528 & 2,327 & 0,201 \\
\hline W1 & 1,1 & 1,205 & 0,105 \\
\hline W2 & 1,8 & 1,851 & 0,051 \\
\hline W3 & 0,6 & 0,699 & 0,099 \\
\hline Panjang GP & 110 & 110,231 & 0,231 \\
\hline Lebar GP & 70 & 70,344 & 0,344 \\
\hline
\end{tabular}

TABEL VI

PERBANDINGAN SPESIFIKASI AWAL,HASIl SIMULASI DAN PENGUKURAN

\begin{tabular}{|c|c|c|c|c|}
\hline Parameter & $\begin{array}{c}\text { Spesifika } \\
\text { si Awal }\end{array}$ & $\begin{array}{c}\text { Hasil } \\
\text { simulasi }\end{array}$ & $\begin{array}{c}\text { Hasil } \\
\text { prototipe }\end{array}$ & Catatan \\
\hline$B W$ & $60 \mathrm{MHz}$ & $60 \mathrm{MHz}$ & $60 \mathrm{MHz}$ & Tercapai \\
\hline VSWR & $\leq 1.5$ & $\leq 1,35$ & $\leq 1,349$ & Tercapai \\
\hline $\begin{array}{c}\text { Pola } \\
\text { Radiasi }\end{array}$ & $\begin{array}{c}\text { Bidirecti- } \\
\text { onal }\end{array}$ & $\begin{array}{c}\text { Bidirecti- } \\
\text { onal }\end{array}$ & $\begin{array}{c}\text { Bidirecti- } \\
\text { onal }\end{array}$ & Tercapai \\
\hline Polarisasi & Linear & - & Elips & Tidak \\
\hline Gain & $\geq 10 \mathrm{dBi}$ & $12,18 \mathrm{dBi}$ & $9,85 \mathrm{dBi}$ & Tercapai \\
\hline $\mathrm{Z}$ & $50 \Omega$ & $\begin{array}{c}44,47+ \\
\mathrm{j} 11,28 \Omega\end{array}$ & $\begin{array}{c}43,481- \\
\mathrm{j} 8,196 \Omega\end{array}$ & Tercapai \\
\hline
\end{tabular}

\section{KESIMPULAN}

Antena dapat bekerja pada frekuensi $10 \mathrm{GHz}$ dengan VSWR $\leq 1.5$ sehingga dapat diimplementasikan untuk aplikasi RADAR. Gain yang didapat berdasarkan hasil pengukuran yaitu 9,85 dBi pada frekuensi $10 \mathrm{GHz}$ dengan Impedansi hasil pengukuran untuk frekuensi 10 $\mathrm{GHz}$ diperoleh 43,841-j3,762 $\Omega$ bersifat kapasitif, sedangkan pada simulasi diperoleh impedansi sebesar $44,47+\mathrm{j} 11,28 \Omega$ bersifat induktif. Karakteristik pola radiasi yang diperoleh adalah bidirectional, polarisasi antena yang diperoleh adalah elips dengan axial ratio sebesar 8,09 dB. Ketepatan dan ketelitian pabrikasi, serta proses pengukuran antena sangat mempengaruhi karakteristik antena yang menyebabkan perbedaan dari hasil simulasi

\section{DAFTAR PUStaka}

[1] D. M. Pozar. and D. H. Schaubert, Microstrip Antennas: The Analysis and Design of Microstrip Antennas and Arrays, New York, IEEE Press, 1995.

[2] I. O. William and D. C. Stuart, The Radio Amateur Antenna Handbook, United States of America, 1978

[3] J. M. Robert, Phased Array Antenna Handbook, Artech House inc., 1994.

[4] M. A. A. Putrawan, "Perancangan dan Implementasi Antena Mikrostrip Susunan Linier Lempeng Persegi pada Frekuensi 2,32,4 GHz", Tugas akhir, Institut Teknologi Telkom, Bandung, 2010.

[5] J. Henry, Antenna Engineering Handbook, McGraw-Hill Inc., 1961. 